f. med. Genet. (1967). 4, 274.

\title{
Diabetes in Wales
}

\author{
DAVID J. B. ASHLEY \\ From Morriston Hospital, Swansed
}

Diabetes mellitus is a biochemical disorder of insulin production and glucose metabolism which is known to be fairly common in the countries that have adequate medical services. Many workers regard the underlying defect as an innate potential biochemical disorder which may become clinically evident as diabetes as a consequence of increasing age or as the result of a change in the environmental stresses to which the individual is subjected, e.g. pregnancy, infection, steroid medication, or obesity (Jackson, 1955). This underlying defect is, in turn, regarded as due to the effect of an abnormal genetic constitution whether this is in a single gene (Harris, 1950; Steinberg, 1959) or to the combined effects of a number of genes working in concert (Simpson, 1964; Thompson, 1965).

\section{Present Investigation}

Recent investigations have shown that the Welsh and non-Welsh components of the population of Wales, who differ little if at all in environment, can be separated on the basis of their surnames, and that genetic differences in blood group genes and in disease susceptibility can be detected (Ashley, 1966, 1967; Ashley and Davies, 1966a, b, c). The techniques used in the previous surveys have been applied to the study of diabetes mellitus in the Principality.

Swansea Cases. Studies were made from the records of Morriston Hospital, Swansea, on 301 patients suffering from diabetes. All were male or young female subjects below marriageable age, and it was assumed that the surname of each was that of his or her father. The group was subdivided into those who lived in the County Borough of Swansea, those who lived in the adjacent parts of the county of Carmarthenshire, and those who lived in the adjacent parts of the county of Glamorgan. In each case the number of people who had a surname included in a list of 96 surnames regarded as Welsh

Received May 5, 1967.
(Ashley and Davies, 1966a, b) was counted, and this was compared with the number to be expected (Table I). The expected numbers were derived from a survey of the electoral registers of the several parts of Wales.

There was an excess of subjects with Welsh surnames in each area and in the group as a whole. The difference was highly significant in the whole group and in the group of patients whose home was in Glamorgan.

TABLE I

CASES OF DIABETES SEEN AT MORRISTON HOSPITAL

\begin{tabular}{c|c|cc}
\hline \multirow{2}{*}{ Home } & \multirow{2}{*}{ Total } & \multicolumn{2}{|c}{ Welsh Names } \\
\cline { 3 - 4 } & & Observed & Expected \\
\hline Swansea & 122 & 63 & 53 \\
Glamorgan & 93 & 63 & 50 \\
Carmarthen & 86 & 61 & 59 \\
\hline Total & 301 & 187 & 162 \\
\hline
\end{tabular}

Deaths from Diabetes. The diabetic state can generally be controlled satisfactorily by attention to the patient's diet and by the administration of insulin or some other hypoglycaemic agent. There are, however, each year a number of deaths in which diabetes is inculpated as a causative factor. The Registrar General's Reports for 1963 and 1964 $(1965,1966)$ give the Standardized Mortality Ratios (S.M.R.) for diabetes for the area of the Welsh Hospital Board, which is coterminous with the Principality of Wales. For men the ratio was 93 in 1963 and 100 in 1964; for women the corresponding ratios were 113 and 131 . Only the last of these four ratios is significantly different from 100 , as the number of deaths involved is small.

When the seven years 1958 to 1964 are taken together the observed number of deaths among men is 513 and the expected number 545.5; the S.M.R. is 94 which is not significantly different from 100 . In the case of females the observed number of 
deaths was 1112 and the expected number 926.1; the S.M.R., 120, is significantly above 100 . These data show that death attributable, at least partially, to diabetes is commoner among women in Wales than among women in England.

These analyses are concerned with Wales as a whole and do not take into account the different components of the population. This difference can be assessed on the basis of the surname and also on the basis of the ability to speak the Welsh language. The two parameters are strongly correlated (Ashley and Davies, 1966a), and the second, the use of the Welsh language, can be used to form a subdivision of Wales into three parts. In one part, the counties of Anglesey, Caernarvon, Cardigan, Carmarthen, and Merioneth, more than $70 \%$ of the population claimed at the 1961 census to be Welsh speaking (Registrar General, 1962b); in the counties of Monmouth and Radnor and in the County Boroughs of Cardiff and Newport less than $10 \%$ of the population were Welsh speaking, while in the remainder of the country between 15 and $45 \%$ of the population were Welsh speaking. These three areas are designated high Welsh, intermediate Welsh, and low Welsh. The total numbers of observed and expected deaths attributed to diabetes in these three areas were calculated for the 5 years, 1958 to 1962, from the Registrar General's Annual Reports for those years and from the 1961 Census Returns (Registrar General, 1960, 1961, 1962a, b, 1963, 1964) (Table II).

\section{TABLE II}

DEATHS ATTRIBUTED TO DIABETES IN WALES 1958-1962

\begin{tabular}{|c|c|c|c|c|c|c|}
\hline & \multicolumn{3}{|c|}{ Males } & \multicolumn{3}{|c|}{ Females } \\
\hline & Observed & Expected & Ratio & Observed & Expected & Ratio \\
\hline $\begin{array}{l}\text { High Welsh } \\
\text { Inter- } \\
\text { mediate }\end{array}$ & 85 & 66.97 & 127 & 157 & $127 \cdot 5$ & 123 \\
\hline $\begin{array}{c}\text { Welsh } \\
\text { Low Welsh }\end{array}$ & $\begin{array}{r}192 \\
76\end{array}$ & $\begin{array}{l}203 \cdot 1 \\
109 \cdot 4\end{array}$ & $\begin{array}{r}106 \\
76\end{array}$ & $\begin{array}{l}448 \\
174\end{array}$ & $\begin{array}{l}363 \cdot 5 \\
163 \cdot 1\end{array}$ & $\begin{array}{l}123 \\
108\end{array}$ \\
\hline
\end{tabular}

In the case of males there is a clear gradient between the high Welsh speaking area with a high S.M.R. and the low Welsh speaking area with a low S.M.R. The difference between the ratios for the high and low Welsh areas is significant. In the case of females the ratios for the two higher Welsh areas are the same and are both greater than the ratio for the low Welsh speaking area.

Hospital Admissions. In 1964 the Ministry of Health published a report on an inquiry into hospital admissions for the year 1961. In the country as a whole the discharge rate for patients suffering from diabetes was $6 \cdot 5$ per 10,000 for males and 8.9 per 10,000 for females. For the hospitals of the Welsh Hospital Board, i.e. for the hospitals of Wales, the discharge rate for men was $7 \cdot 6$ per 10,000 and that for women was $10 \cdot 7$ per 10,000 . The rate for men was highest among the 15 hospital region areas, that for women was third.

\section{Discussion}

The frequency of diabetes among the Welsh people of Wales has been investigated from three points of view. The hospital admission rate for this disease is high in Wales relative to the rest of the country. Deaths attributable to diabetes are commoner among women in Wales than in England and, within the Principality, are higher both for men and for women in the areas in which Welsh is a commonly spoken language. Finally, there is an excess of Welsh surnames among patients suffering from diabetes in the hospital of South West Wales which was studied. The evidence from these three sources taken together points to a difference between the Welsh and non-Welsh people of Wales, which is reflected in their different susceptibilities to the clinical disease diabetes mellitus.

It is probable (Jackson, 1955) that the clinical disease is the result of the interaction between the genetic constitution and the internal and external environment. The external environments of the Welsh and non-Welsh people of Wales are similar in occupation, social status, and housing (Ashley and Davies, 1966a); a preliminary survey has shown no difference in fertility and it seems reasonable to conclude that the observed differences are due to a difference between the gene pools of the Welsh of Wales and the non-Welsh immigrants.

This survey offers no assistance in resolving the conflict between the single gene and multifactorial hypotheses of the genetic factors in diabetes (Harris, 1950; Steinberg, 1959; Simpson, 1964; Thompson, 1965); in either event it is the prevalence of the genes in each of the two populations which is manifest as the frequency of clinical diabetes.

\section{Summary}

The distribution of diabetes mellitus in Wales has been studied. There is a relative excess of this disease in those parts of the Principality in which Welsh is commonly spoken, and there is an excess of patients with Welsh surnames among patients suffering from this disease in South West Wales.

It is suggested that this difference between the 
Welsh and the non-Welsh is due to a difference in the gene pools of the two groups of people in respect of the gene or genes concerned in the aetiology of diabetes mellitus.

This work was carried out with the aid of a research grant from the Welsh Hospital Board.

\section{REFERENCES}

Ashley, D. J. B. (1966). Observations on the epidemiology of r rostatic hyperplasia in Wales. Brit. F. Urol., 38, 567.

-1 (1967). Coronary artery disease in Wales. F. med. Genet., 4, 277.

- , and Davies, H. D. (1966a). The use of the surname as a genetic marker in Wales. F. med. Genet., 3, 203.

, and - (1966b). Gastric cancer in Wales. Gut, 7, 542.

, and - (1966c). Lung cancer and chronic bronchitis in Wales. Brit. F. prev. soc. Med., 20, 148.

Harris, H. (1950). The familial distribution of diabetes mellitus : a study of the relatives of 1241 diabetic propositi. Ann. Eugen. (Lond.), 15, 95.

Jackson, W. P. U. (1955). A concept of diabetes. Lancet, 2, 625.
Ministry of Health (1964). Report on Hospital In-Patient Enquiry for the Year 1961. II Detailed Tables. H.M.S.O., London.

Registrar General (1960). Statistical Review of England and Wales for the Year 1958. Part I. Tables Medical. H.M.S.O., London.

- (1961). Statistical Review of England and Wales for the Year 1959. Part I. Tables Medical. H.M.S.O., London.

(1962a). Statistical Review of England and Wales for the Year 1960. Part I. Tables Medical. H.M.S.O., London.

- (1962b). Census Report for 1961 on Welsh Speaking Population. H.M.S.O., London.

- (1963). Statistical Review of England and Wales for the Year 1961. Part I. Tables Medical. H.M.S.O., London.

(1964). Statistical Review of England and Wales for the Year 1962. Part I. Tables Medical. H.M.S.O., London.

- (1965). Statistical Review of England and Wales for the Year 1963. Part I. Tables Medical. H.M.S.O., London.

(1966). Statistical Review of England and Wales for the Year 1964. Part I. Tables Medical. H.M.S.O., London.

Simpson, N. E. (1964). Multifactorial inheritance: a possible hypothesis for diabetes. Diabetes, 13, 462 .

Steinberg, A. G. (1959). The genetics of diabetes: a review. Ann. N.Y. Acad. Sci., 82, 197.

Thompson, G. S. (1965). Genetic factors in diabetes mellitus, studied by the oral glucose tolerance test. f. med. Genet., 2, 221. 